\title{
Is tocilizumab effective in cytokine release syndrome in patients diagnosed with COVID-19?: a retrospective preliminary study
}

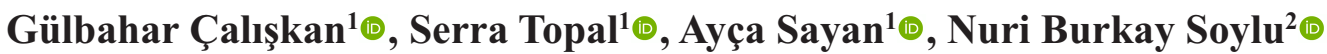 \\ ${ }^{1}$ Department of Anesthesiology and Intensive Care, Bursa City Hospital, Bursa, Turkey \\ ${ }^{2}$ Department of Anesthesiology and Intensive Care, Uludag University, Faculty of Medicine, Bursa, Turkey
}

\begin{abstract}
Objectives: Although the prognosis is good in the vast majority of patients who are diagnosed with COVID19, there are cases in which Acute Respiratory Distress Syndrome (ARDS) and multiple organ failure occur rapidly and result in death in a short time. It has been reported that severe clinical presentation is caused by cytokine release syndrome, and studies are currently conducted on treatments to reduce mortality in these patients. There are studies reporting the positive effects of anti-Human IL-6 Receptor Monoclonal Antibody, tocilizumab (TCZ), which specifically inhibits the functions of IL-6, in cases with cytokine storm. Data on TCZ use in intensive care are very limited.

Methods: The medical records of 20 patients diagnosed with COVID-19 who were treated with standard treatment and TCZ in the ICU were retrospectively reviewed.

Results: Twenty patients were included in the review. Nine $(45 \%)$ received TCZ. The median length of stay in the ICU was 20 days in the TCZ group, and 14 days in the standard treatment group $(p=0.21)$. Mortality rate was $22.2 \%$ in TCZ group and $45.5 \%$ in the standard treatment group ( $p=0.27$ ).

Conclusions: At day 28, mortality rate and clinical improvement was not statistically different in patients receiving standard treatment with $\mathrm{TCZ}$ and patients in standard treatment group. Additional data are needed to understand the eficacy and safety of TCZ.
\end{abstract}

Keywords: COVID-19, cytokine release syndrome, tocilizumab

C oronaviruses are RNA viruses that can infect humans and many animal species [1]. Although they cause seasonal respiratory tract infections in humans, new Coronavirus species, especially the ones that have been seen since 2002 , have led to clinical presentations characterized by a more severe respiratory tract infection. These are Severe Acute Respiratory Syndrome (SARS) and Middle East Respiratory Syndrome (MERS) infections that emerged in 2003 and 2012 respectively and caused hundreds of deaths $[1,2]$. On December 31, 2019, cases of pneumonia of unknown etiology were reported in Wuhan, China's
Hubei province, and a new coronavirus (2019-nCoV) that was not previously detected in humans was identified as a causative agent. Later, the name of the 2019$\mathrm{nCoV}$ disease was accepted as coronavirus disease 2019 (COVID-19), and it spread rapidly in China and many other countries, reaching the pandemic level [3].

Although the prognosis is generally good in COVID-19, it has been reported that approximately $20 \%$ of the patients develop severe pneumonia that can progress to Acute Respiratory Distress Syndrome (ARDS) [1]. Clinical data show that in patients with ARDS, the virus can induce an exaggerated abnormal

2How to cite this article: Çallşkan G, Topal S, Sayan A, Soylu NB. Is tocilizumab effective in cytokine release syndrome in patients diagnosed with COVID-19: a retrospective preliminary study? Eur Res J 2022;8(1):84-90. DOI: 10.18621/eurj.938778

Address for correspondence: Gülbahar Çallşkan, MD., Bursa City Hospital, Department of Anesthesiology and Intensive Care, 16110, Bursa, Turkey. E-mail: alkanbahar@yahoo.com,Tel: +902249752244,Fax: 902242680062 
host immune response characterized by an excessive increase of pro-inflammatory cytokines similar to the clinical and serological features of cytokine release syndrome [4]. Cytokine release syndrome is one of the main causes of the clinical picture resulting in cardiovascular collapse, multiple organ failure and rapid death. Therefore, in cases which cytokine storm develops, it is thought that neutralization of inflammatory factors is an effective treatment in reducing mortality [5].

The main driver of cytokine storm is interleukin 6 (IL-6). IL-6 is produced by activated leukocytes and acts on a large number of cells and tissues. Although positive clinical results have been reported in patients who developed cytokine release syndrome and used anti-human IL-6 receptor monoclonal antibody tocilizumab (TCZ), which specifically inhibits the functions of IL-6, data with high level of evidence about the effect of TCZ on inflammatory activity patients with COVID-19 is not yet available $[6,7]$.

There is currently no standardized therapeutic scheme for the use and dosage of tocilizumab in the treatment of cytokine storm caused by COVID-19, and data on its use in intensive care are very limited. In our retrospective study, we aimed to reveal the effects of using TCZ on clinical results and laboratory values in patients diagnosed with COVID-19 and developed cytokine release syndrome in the intensive care unit (ICU).

\section{METHODS}

\section{Study Design and Participants}

Patients above 18 years of age who were admitted to Bursa City Hospital, Department of Anesthesiology and Reanimation Intensive Care Unit between April 5 - June 20, 2020 and diagnosed COVID-19 which was confirmed with reverse transcription polymerase chain reaction (rRT-PCR) and received either a standard treatment with TCZ and standard treatment without TCZ were enrolled in the study. Patients who received immune plasma and steroid treatment were excluded. The study was approved by the ethical committee of Uludag University Faculty of Medicine.

\section{Procedures}

The data of the patients were obtained from the medical records. The demographic data (age, gender), various scores for predicting morbidity and mortality (Acute Physiology and Chronic Health Evaluation [APACHE] II and Sequential Organ Failure Assessment $[\mathrm{SOFA}]$ ), body temperature, $\mathrm{PaO} 2 / \mathrm{FiO} 2$ ratio and duration of ICU hospitalization were recorded for each patient. The latest C-reactive protein (CRP), IL6, ferritin, lactate dehydrogenase (LDH), d-dimer, lymphocyte and neutrophil values before TCZ administration were chosen as pre-treatment values and changes in values within the seven-day period after TCZ administration were taken into account. In the standard treatment group, the values of these data at the time of ICU hospitalization were recorded. The demographic characteristics, ICU hospitalization scores, laboratory data, length of ICU hospitalization and 28day mortality rates of the patient group treated with tocilizumab and standard therapy were compared. In addition, the pre-treatment laboratory and clinical data of the TCZ group were compared with the data on the 3rd and 7th days of treatment.

\section{Treatment}

In our intensive care unit, this treatment was applied in cases diagnosed with pneumonia, in line with the recommendations of the Ministry of Health General Directorate of Public Health Covid-19 (SARSCoV-2) Guide [8]: Hydroxychloroquine with a loading dose of $400 \mathrm{mg}$ twice daily followed by $200 \mathrm{mg}$ per day twice daily for additional five days, favipravir with a loading dose of $1600 \mathrm{mg}$ twice daily followed by $600 \mathrm{mg}$ per day twice daily for additional five days and azithromycin with a loading dose of $500 \mathrm{mg}$ daily followed by $250 \mathrm{mg}$ per day for additional five days, unless contraindicated. CRP, IL-6, ferritin, neutrophil, lymphocyte count, procalcitonin (PCT) and D-dimer values were monitored daily or at 48 hour intervals according to the fever and $\mathrm{PaO} 2 / \mathrm{FiO} 2$ ratio of the cases. In patients with suspected cytokine release syndrome in their follow-up, after secondary bacterial infection was excluded, the first dose of TCZ was administered as a 1-hour infusion of $400 \mathrm{mg}$, and the second dose of $400 \mathrm{mg}$ was administered 24 hours later to those who did not show improvement in $\mathrm{PaO} 2 / \mathrm{FiO} 2$ ratio.

\section{Adverse Effects}

The occurrence of adverse events was recorded daily and focused on: bacterial or fungal infections, 
elevation aspartat transaminase (AST) or alanine aminotransaminase (ALT) level $>5$ fold the upper limit of normal range (AST:0-40 IU/L, ALT:0-41 $\mathrm{IU} / \mathrm{L}$ ), neutropenia $<1.0103 / \mu \mathrm{L}$, thrombocytopenia $<$ $100103 / \mu \mathrm{L})$.

\section{Statistical Analysis}

The data were analyzed using SPSS 26.0 for Windows (SPSS, Chicago, IL). The frequency and descriptive statistics were calculated. The descriptive statistics were presented as \pm SD for continuous variables, while they were presented as median (min-max) for the categorical variables. Independent samples $t$ test (Student's t test) and Mann Whitney-U test were performed to compare variables between two treatment groups. Before performing these tests, the data were explored by using Kolmogorov-Smirnov test which datas were normally distributed. Chi-Square test was used to compare categorical variables between the groups. Friedman test was used to compare the varibles of patients whom treatment $\left(72^{\text {th }}\right.$. hour and $1^{\text {st }}$. week). To find out which pairs are different, pairwise comparions post-hoc Bonferroni test was carried out. The level of statistical significance was set at $p<$ 0.05 .

\section{RESULTS}

During the study, a total of 31 patients whose COVID-19 diagnosis was confirmed by rRT-PCR were followed up in the intensive care unit. Nine (29\%) cases received TCZ with standard therapy, and 11 cases only received standard therapy. Three patients given immune plasma, 7 patients treated with steroids and 1 patient for whom sufficient data could not be obtained were excluded from the study. Baseline characteristics of both groups are summarized in Table 1 . Median age was similar in the tocilizumab and the standard treatment group: 62 (46-76), compared to 65

Table 1. Baseline characteristics of the patients

\begin{tabular}{|c|c|c|c|}
\hline & $\begin{array}{c}\text { Tocilizumab } \\
(\mathbf{n}=9)\end{array}$ & $\begin{array}{c}\text { Standartd } \\
\text { treatmant } \\
(n=11)\end{array}$ & $p$ value \\
\hline Age (years) (median, min-max) & $62.67(46-79)$ & $65(37-81)$ & 0.673 \\
\hline \multicolumn{4}{|l|}{ Gender ( $\mathrm{n}, \%$ of total) } \\
\hline Male & $9(45 \%)$ & $7(35 \%)$ & 0.094 \\
\hline Female & $0(0 \%)$ & $4(20 \%)$ & \\
\hline Body mass index $\left(\mathrm{kg} / \mathrm{m}^{2}\right)$ (median, min-max) & $26.97(25-30)$ & $28.45(23-33)$ & 0.254 \\
\hline APACHE-II (median, min-max) & $19.11(7-30)$ & $17.72(7-31)$ & 0.666 \\
\hline SOFA (median, min-max) & $4(3-11)$ & $4(3-14)$ & 0.261 \\
\hline Fever $\left({ }^{\circ} \mathrm{C}\right)$ (median, min-max) & $37.5(36.8-39.1)$ & $37.5(36.5-39.3)$ & 0.987 \\
\hline \multicolumn{4}{|l|}{ Co-morbidites ( $\mathrm{n}, \%$ of total) } \\
\hline Diabtes mellitus & $2(10 \%)$ & $3(15 \%)$ & 0.604 \\
\hline Hypertension & $3(15 \%)$ & $4(20 \%)$ & 0.630 \\
\hline COPD & $0(0 \%)$ & $1(5 \%)$ & 0.550 \\
\hline Coronary artery disease & $3(15 \%)$ & $0(0 \%)$ & 0.074 \\
\hline Cerebrovascular disease & $2(10 \%)$ & $0(0 \%)$ & 0.189 \\
\hline $\begin{array}{l}\text { Patients required invasive mechanical ventilation } \\
\text { (n, \% of total) }\end{array}$ & $4(20 \%)$ & $4(20 \%)$ & 0.535 \\
\hline $\begin{array}{l}\text { Patients required high flow oxygen therapy } \\
\text { (n, \% of total) }\end{array}$ & $5(25 \%)$ & $7(35 \%)$ & 0.535 \\
\hline
\end{tabular}

APACHE II = Acute Physiology and Choronic Health Evaluation, SOFA = Sequential Organ Failure Assessment, $\mathrm{COPD}=$ Choronic obstructive pulmonary disaese 


\begin{tabular}{|c|c|c|c|c|}
\hline & $\begin{array}{c}\text { Tocilizumab } \\
\quad(n=9)\end{array}$ & $\begin{array}{c}\text { Standartd } \\
\text { treatmant } \\
(\mathrm{n}=11)\end{array}$ & $\begin{array}{l}\text { Reference } \\
\text { range }\end{array}$ & $p$ value \\
\hline Interleukin-6 level (pg/mL) & $\begin{array}{l}153.650 \pm 3 \\
(39-283)\end{array}$ & $\begin{array}{l}296 \pm 143 \\
(15-1655)\end{array}$ & $0-7$ & 0.930 \\
\hline C-reactive protein $(\mathrm{mg} / \mathrm{L})$ & $\begin{array}{c}159.5 \pm 78.9 \\
(47.5-287)\end{array}$ & $\begin{array}{l}126.5 \pm 62.1 \\
(51-248)\end{array}$ & $0-5$ & 0.307 \\
\hline Procalcitonin $(\mu \mathrm{g} / \mathrm{L})$ & $\begin{array}{c}1.0 \pm 0.2 \\
(0.12-2.15)\end{array}$ & $\begin{array}{c}1.1 \pm 0.4 \\
(0.06-5.27)\end{array}$ & - & 0.824 \\
\hline Ferritin (ng/mL) & $\begin{array}{l}1494.2 \pm 438.5 \\
(963-2000)\end{array}$ & $\begin{array}{l}992.3 \pm 676.1 \\
(185-2000)\end{array}$ & $30-400$ & 0.071 \\
\hline Neutrophil count $\left(10^{3} / \mu \mathrm{L}\right)$ & $\begin{array}{c}9.9 \pm 3.0 \\
(5.7-13.9)\end{array}$ & $\begin{array}{c}7.0 \pm 2.4 \\
(3.7-11.3)\end{array}$ & $1.8-6.98$ & $0.028^{*}$ \\
\hline Lymphocyte count $\left(10^{3} / \mu \mathrm{L}\right)$ & $\begin{array}{l}0.85 \pm 0.12 \\
(0.34-1.70)\end{array}$ & $\begin{array}{l}0.87 \pm 0.14 \\
(0.48-2.17)\end{array}$ & $1.26-3.35$ & .882 \\
\hline Platelet count $\left(10^{3} / \mu \mathrm{L}\right)$ & $\begin{array}{c}304.8 \pm 93.8 \\
(155-467)\end{array}$ & $\begin{array}{c}255.4 \pm 96.3 \\
(109-422)\end{array}$ & $166-308$ & 0.264 \\
\hline $\begin{array}{l}\text { Lactate dehydrogenase } \\
\text { (IU/L) }\end{array}$ & $\begin{array}{l}499.1 \pm 170.7 \\
(277-789)\end{array}$ & $\begin{array}{c}467.2 \pm 146.0 \\
(246-743)\end{array}$ & $135-225$ & 0.658 \\
\hline D-dimer (ug/FEU/ml) & $\begin{array}{c}3.2 \pm 3.1 \\
(0.65-8.93)\end{array}$ & $\begin{array}{c}2.5 \pm 3.4 \\
(0.25-9.87)\end{array}$ & $0-0.5$ & 0.665 \\
\hline Troponin (ng/L) & $\begin{array}{c}31.6 \pm 44.4 \\
(7.7-111)\end{array}$ & $\begin{array}{l}26.1 \pm 31.9 \\
(5-111)\end{array}$ & - & 0.781 \\
\hline
\end{tabular}

*The level of statistical significance was set at $p<0.05, * *$ Data were presented as mean $\pm \mathrm{SD}(\min -\mathrm{max})$

(37-81) years respectively $(p=0.67)$. Median body mass index was 26 and 28 in the tocilizumab and the standard treatment group, respectively $(p=0.25)$. In addition, no statistically significant difference was found between the two groups in terms of ICU hospitalization scores and co-morbidities.

The median values of $\mathrm{PaO} 2 / \mathrm{FiO} 2$ ratios were 79.7 and 107.2 in the TCZ and standard treatment groups, respectively $(p=0.60)$. When we evaluated the two groups within themselves, the $\mathrm{PaO}_{2} / \mathrm{FiO}_{2}$ ratios in the first week were $159.2 \pm 70.2(p=0.001)$ and $125.6 \pm$ $63.6(p=0.006)$, respectively, and the increase in both groups was statistically significant.

While $4(44.4 \%)$ patients were under invasive mechanical ventilation (IMV) support before treatment in the TCZ group, 5 (55.6\%) patients received high flow oxygen therapy (HFOT). While the need for IMV support continued in 4 patients in the first week after the treatment, one of the patients who received HFOT was taken to nasal oxygen support. In the standard treatment group, $4(36.5 \%)$ patients were under IMV support, while $7(63.6 \%)$ patients were undergoing HFOT, and the patients' IMV and HFOT need continued on the 7th day of their admission to the ICU.

There was no statistically significant difference between the laboratory findings of both groups, except for neutrophil levels (Table 2). The length of stay in the ICU was $20.63 \pm 12.58$ days in the tocilizumab group and $14.36 \pm 8.78$ dayin the standard treatment group $(p=0.21)$. By day 28 , two $(22.2 \%)$ patients in the tocilizumab group compared to $5(\% 45,5)$ patients in the standard treatment group died $(p=0.27)$. The time from onset of symptoms to treatment administration in the TCZ group was $11.5 \pm 5.7$ (5-19) days.

Before starting TCZ therapy, CRP $(159.5 \mathrm{mg} / \mathrm{L})$, ferritin (1494.2 ng/mL), IL-6 (153.6 pg/mL) values 
were significantly higher in all patients. A statistically significant decrease was found in CRP $(14 \mathrm{mg} / \mathrm{L})$ and ferritin $(897.1 \mathrm{ng} / \mathrm{mL})$ values in the first week after treatment ( $p=0.001$ and $p=0.018$, respectively). There was a significant rapid increase $(1958 \mathrm{pg} / \mathrm{mL})$ in IL-6 values on the 3rd day after treatment and a decreasing trend was observed. The SOFA scores, $\mathrm{PaO} 2 / \mathrm{FiO} 2$ ratios and laboratory findings of the patients in TCZ group at pre-treatment, at the 72nd hour and at the first week of treatment are summarized in Table 3. While CRP values improved rapidly after TCZ treatment, there was a gradual decrease in ferritin values.

Thrombocytopenia, neutropenia, and elevation of liver enzymes were not detected in the TCZ group during ICU hospitalization. Ventilator-associated pneumonia developed in one patient $(11.1 \%)$ in this group, and central catheter-related bloodstream infection developed in one patient $(9.1 \%)$ in the standard treatment group.

All patients had chest computed tomography at the time of their admission to ICU and all had bilateral lung diseases. In TCZ group, 5 patients had bilateral ground glass opacities with peripheral and central distribution, 3 patients had bilateral ground glass opacities with peripheral distribution and bilateral lower lobes were involved in only one patient. In standart treatment group, 2 patients had bilateral ground glass opacities with peripheral and central distribution, 5 patients had bilateral ground glass opacities with peripheral distribution and bilateral lower lobes were involved in 4 patients.

\section{DISCUSSION}

Although the mechanism of organ dysfunctions in severe COVID-19 cases is not clearly demonstrated, it has been revealed that at least some of the organ dysfunctions are immune-mediated with the increase in proinflammatory cytokine levels such as tumor necrosis factor $-\alpha$, IL- $1 \beta$, IL- 6 , which play a role in cytokine storm. As a result of these studies, in addition to antiviral and supportive treatments, immunotherapeutic agents were used in severe COVID-19 infection [9$11]$.

In this study, in which we share preliminary data regarding TCZ use in patients diagnosed with COVID-19 in Bursa City Hospital, in the province of Bursa where the number of cases are one of the highest in Turkey; we found that the use of tocilizumab did not significantly affect the 28-day ICU stay compared

Table 3. Parameters at admission, 72 hours and 1 week after treatment with tocilizumab

\begin{tabular}{|c|c|c|c|c|c|c|c|}
\hline & \multirow{2}{*}{$\begin{array}{l}\text { Before } \\
\text { treatment }\end{array}$} & \multirow{2}{*}{$\begin{array}{c}72 \text { hours after } \\
\text { treatment }\end{array}$} & \multirow{2}{*}{$\begin{array}{c}1 \text { week after } \\
\text { treatment }\end{array}$} & \multirow[t]{2}{*}{$p$ value } & \multicolumn{3}{|c|}{ Pairwise comparisons } \\
\hline & & & & & $\begin{array}{c}\text { Before } \\
\text { treatmen } \\
\text { t vs at } 72 \\
\text { hours }\end{array}$ & $\begin{array}{c}72 \text { hours } \\
\text { after vs } \\
\text { at } 1^{\text {st }} \\
\text { week }\end{array}$ & $\begin{array}{c}\text { Before } \\
\text { treatment } \\
\text { vs after } 1^{\text {st }} \\
\text { week }\end{array}$ \\
\hline $\begin{array}{l}\text { SOFA } \\
\text { (respiratory) }\end{array}$ & $4(0-4)$ & $3(0-4)$ & $2.5(0-4)$ & $0.007^{*}$ & 0.634 & 0.634 & $0.037^{*}$ \\
\hline $\begin{array}{l}\mathrm{PaO} 2 / \mathrm{FiO} 2 \\
\text { Ratio }\end{array}$ & $\begin{array}{c}79.7 \pm 15.9 \\
(59-105)\end{array}$ & $\begin{array}{c}117.7 \pm 38.5 \\
(78-202)\end{array}$ & $\begin{array}{c}159.2 \pm 70.2 \\
(83-296)\end{array}$ & $0.001^{*}$ & 0.073 & 0.401 & $0.001 *$ \\
\hline $\begin{array}{l}\text { Interleukin-6 } \\
\text { level (pg/mL) }\end{array}$ & $\begin{array}{c}153.650 \pm 3 \\
(39-283)\end{array}$ & $1938 \pm 2049.1$ & $\begin{array}{c}1588.8 \pm 1522.4 \\
(223-3504)\end{array}$ & $0.015^{*}$ & $0.004 *$ & 0.343 & 0.058 \\
\hline $\begin{array}{l}\text { C-reactive } \\
\text { protein }(\mathrm{mg} / \mathrm{L})\end{array}$ & $\begin{array}{c}159.5 \pm 78.9 \\
(47.5-287)\end{array}$ & $61 \pm 77.3$ & $\begin{array}{l}14 \pm 8.6 \\
(3.1-26)\end{array}$ & $0.001^{*}$ & 0.061 & 0.061 & $0.001 *$ \\
\hline $\begin{array}{l}\text { Ferritin } \\
(\mathrm{ng} / \mathrm{mL})\end{array}$ & $\begin{array}{c}1494.2 \pm \\
438.5\end{array}$ & $\begin{array}{c}1101.3 \pm 497.8 \\
(594-2000)\end{array}$ & $\begin{array}{c}897.1 \pm 343.3 \\
(649-1716)\end{array}$ & $0.021^{*}$ & 0.952 & 0.240 & $0.018^{*}$ \\
\hline $\begin{array}{l}\text { Neutrophil } \\
\text { count }(103 / \mu \mathrm{L})\end{array}$ & $\begin{array}{l}9.94 \pm 3.07 \\
(5.77-13.9)\end{array}$ & $\begin{array}{l}7.67 \pm 5.11 \\
(2.16-15.7)\end{array}$ & $\begin{array}{c}8.65 \pm 7.11 \\
(3.6-23.6)\end{array}$ & 0.417 & - & - & - \\
\hline
\end{tabular}

SOFA $=$ Sequential Organ Failure Assessment, ${ }^{*}$ The level of statistical significance was set at $\mathrm{p}<0.05,{ }^{* *}$ Data were presented as mean $\pm \mathrm{SD}(\min -\max )$ 
to standard treatment.

TCZ treatment was applied in our clinic in line with the recommendations of the Ministry of Health Guide: For the diagnosis of macrophage activation syndrome (MAS) characterized by cytokine storm, changes in clinical and laboratory findings within hours or days should be considered instead of crosssectional evaluation based on one measurement [8]. In our study, the average time from the onset of symptoms of COVID-19 infection to administration of TCZ was 11 days. Radbel et al. [12] applied TCZ treatment on the 9th day after the onset of symptoms in one patient and on the 7th day in one patient, and they reported poor results in both cases. In a study using tocilizumab on average 2 days after the onset of symptoms, shorter invasive mechanical ventilation and clinical recovery time were reported, although not statistically significant [13]. These studies demonstrate the need for clinical research to determine optimal patient selection and timing.

There are no data with a high level of evidence regarding the dose of TCZ use [12, 14, 15]. Considering the changes in clinical and laboratory findings, TCZ in our clinic was administered as a second dose of 400 $\mathrm{mg}$ within 24 hours. Despite the usage of high dose TCZ, thrombocytopenia, neutropenia and increase in liver enzymes were not observed.

In our study, all patients had bilateral lung disease and we compared the two groups. Results of the comparison demonstrate that there was no difference in not only the baseline characteristics of the two groups but also we found no significant difference in terms of intensive care stay and $\mathrm{PaO} 2 / \mathrm{FiO} 2$ ratios betwee two groups.

As a result of the analysis of pre-treatment laboratory data in the TCZ group, we found that CRP and ferritin decreased consistently when compared with the values on the 3rd and 7th days of treatment. Whether this downward trend of acute phase reactants is related to clinical improvement is not yet clear [13]. The dramatic CRP reduction after treatment is a pharmacological effect of TCZ through the IL-6 receptor. We found a significant increase in IL-6 levels on the 3rd day of treatment. A possible explanation for this is that tocilizumab inhibits receptor-mediated clearance of IL-6, leading to serum accumulation [14].

Limitations
The lack of a control group and the small number of patients in studies with promising results regarding tocilizumab are important limitations of these studies $[9,14,16]$. In studies conducted after these studies and comparing tocilizumab with standard therapy, no statistical difference was found between the groups in mortality and intensive care unit admission $[17,18]$.

\section{CONCLUSION}

The diagnosis of MAS and initiation of treatment within hours is very important in suppressing the cytokine storm. Although it is still difficult to use laboratory parameters to define the disease activity, the amount of dose to be applied in the treatment is not clear. We think that the results of clinical studies with large patient groups will provide further evidence on the role of IL- 6 blockade in severe COVID-19 patients and whether tocilizumab treatment is safe and effective.

\section{Authors' Contribution}

Study Conception: GÇ, ST, AS; Study Design: GÇ, ST, AS; Supervision: GÇ, ST, NBS; Funding: GÇ; Materials: GÇ; Data Collection and/or Processing: ST, AS, NBS; Statistical Analysis and/or Data Interpretation: GÇ, ST, AS, NBS; Literature Review: GÇ, AS, NBS; Manuscript Preparation GÇ, ST and Critical Review: GÇ, ST, AS, NBS.

\section{Conflict of interest}

The authors disclosed no conflict of interest during the preparation or publication of this manuscript.

\section{Financing}

The authors disclosed that they did not receive any grant during conduction or writing of this study.

\section{Acknowledgements}

We thank Sinem Akselim for their support. We dedicate this work to healthcare professionals who lost their lives during the the Coronavirus outbreak.

\section{REFERENCES}

1. Wu J, Yuan Z, Wang B, Gu R, Li W, Xiang X, et al. Severe 
acute respiratory syndrome coronavirus 2 : from gene structure to pathogenic mechanisms and potential therapy. Front Microbiol 2020;11:1576.

2. Hozhabri H, Sparascio FP, Sohrabi H, Mousavifar L, Roy R, Scribano D, et al. The global emergency of novel coronavirus (SARS-CoV-2): an update of the current status and forecasting. Int J Environ Res Public Health 2020;16:5648.

3. Dhama K, Khan S, Tiwari R, Sircar S, Bhat S, Malik YS, et al. Coronavirus disease 2019-COVID-19. Clin Microbiol Rev 2020;33:e00028-20.

4. Picchianti Diamanti $A$, Rosado $M M$, Pioli $C$, Sesti $G$, Laganà B. Cytokine release syndrome in COVID-19 patients, A new scenario for an old concern: the fragile balance between infections and autoimmunity. Int J Mol Sci 2020;21:3330.

5. Zhanga C, Wua Z, Li JW, Zhaoa H, Wang GQ. Cytokine release syndrome in severe COVID-19: interleukin-6 receptor antagonist tocilizumab may be the key to reduce mortality. Int J of Antimicrobial Agents 2020;55:105954.

6. Fu B, Xu X, Wei H. Why tocilizumab could be an efective treatment for severe COVID-19? J Transl Med 2020;18:164.

7. Ulhaq ZS, Soraya GV. Interleukin-6 as a potential biomarker of COVID-19 progression. Med Mal Infect 2020;50:382-3.

8. Repuclic of Turkey Ministry of Health General Directorate of Public Health Covid-19 (SARS-CoV-2) Guide. Available from:https://covid19.saglik.gov.tr/Eklenti/37702/0/covid-19rehberiantisitokin-antiinflamatuartedavilerkoagulopatiyonetimipdf.pdf Accessed 2020 June 1.

9. Ortiz-Prado E, Simbaña-Rivera K, Gómez- Barreno L, RubioNeira M, Guaman LP, Kyriakidis NC, et al. Clinical, molecular, and epidemiological characterization of the SARS-CoV-2 virus and the coronavirus disease 2019 (COVID-19), a comprehensive literature review. Diagn Microbiol Infect Dis 2020;98:115094. 10. Buckley LF, Wohlford GF, Ting C, Alahmed A, Van Tassell BW, Abbate A, et al. Role for anti-cytokine therapies in severe coronavirus disease 2019. Crit Care Explor 2020;2:e0178.

11. Odabasi Z, Cinel İ. Consideration of severe coronavirus disease 2019 as viral sepsis and potential use of immune checkpoint inhibitors. Crit Care Explor 2020;2:e0141.

12. Radbel J, Narayanan N, Bhatt PJ. Use of tocilizumab for COVID-19-induced cytokine release syndrome: a cautionary case report. Chest 2020;158:e15-19.

13. Kewan T, Covut F, Al-Jaghbeer MJ, Rose L, Gopalakrishna $\mathrm{KV}$, Akbik B. Tocilizumab for treatment of patients with severe COVID-19: a retrospective cohort study. EClinicalMedicine 2020;24:100418.

14. Luo P, Liu Y, Qiu L, Liu X, Liu D, Li J. Tocilizumab treatment in COVID-19: a single center experience. J Med Virol 2020;92:814-8.

15. De Rossia N, Scarpazzab C, Filippinia C, Cordiolia C, Rasiaa $\mathrm{S}$, Mancinellia CR. Early use of low dose tocilizumab in patients with COVID-19: a retrospective cohort study with a complete follow-up. EClinicalMedicine 2020;25:100459.

16. Fu B, Xu X, Wei H. Why tocilizumab could be an efective treatment for severe COVID-19? J Transl Med 2020;18:164.

17. Campochiaroa C, Della-Torrea E, Cavallia G, De Lucaa G, Ripa M, Boffini N, et al. Efficacy and safety of tocilizumab in severe COVID-19 patients: a single centre retrospective cohort study. Eur J Intern Med 2020;76:43-9.

18. Colaneri M, Bogliolo L, Valsecchi P, Sacchi P, Zuccaro V, Brandolino F, et al. Tocilizumab for treatment of severe COVID19 patients: preliminary results from SMAtteo COvid19 REgistry (SMACORE). Microorganisms 2020;8:695. 